\title{
新生児聴覚スクリーニング開始後, 13年間に当科を受診した難聴児の調査
}

\author{
鈴木雪恵 ${ }^{1)}$, 今泉光雅 ${ }^{2)}$, 馬場陽子 ${ }^{3)}$, 鈴木輝久 ${ }^{4)}$, 山田奈保子 ${ }^{1)}$, \\ 原田 綾1)，黑田令子 ${ }^{2)}$, 大柣好史 ${ }^{2)}$, 菊地大介 ${ }^{2)}$, 小川 洋 ${ }^{5}$ \\ 1)福島県総合療育センター \\ 2)福島県立医科大学耳鼻咽喉科学講座 \\ ${ }^{3)}$ ばばクリニック \\ 4)すずき耳・鼻・のどクリニック \\ 5)福島県立医科大学会津医療センター
}

\begin{abstract}
要旨: 福島県総合療育センターにおいて 2004 年 4 月からの13年間に新生児聴覚スクリーニ ング（以下, NHS）後, 精密聴力検査を受けた 220 名と NHS パス後難聴と診断された 45 名について聴力検查結果と補装具の使用状況及び原因因子について調查した。当センター で療育中の難聴児 233 名中 45 名 $19.3 \%$ が NHS パス症例であり, 進行性・後天性難聴児の 早期発見も重要であることがわかった。一側要再検後及び NHS パス後, 両側難聴診断症 例では両側軽・中等度難聴が多かった。原因因子は，両側難聴診断症例では遺伝的素因，

一側難聴診断症例では外耳道狭窄症が最多であった。
\end{abstract}

$$
\text { ーキーワードー }
$$

新生児聴覚スクリーニング, 原因因子, 新スク pass 後, 難聴

\section{はじめに}

福島県では，新生児聴覚スクリーニング（以下， NHS）は2004年 1 月から実施されている。現在は 38分娩施設中 37 施設で実施可能であり, 県内ほぼ $100 \%$ 新生児が NHS を受けられる体制が整って いる。福島県の精密聴覚検査実施機関は福島県総合 療育センター（当センター）を含め 4 病院, 療育機 関は当センターを含め 2 病院であり, 当センターは 福島県に拄ける難聴児の $90 \%$ 以上を療育している。

2004年 4 月から 2017 年 3 月までの13年間に当セン ターでNHS 要再検後に精密聴力検査を受けた症例 は220名, NHS パス後に難聴が疑われ当センターを 受診した症例171名であった。

今回当センターで NHS 要再検症例の精密聴力検 査結果, NHS パス後難聴が発見された症例の聴力
検査結果，それぞれの原因因子について調査を行っ たので報告する。

\section{対象と方法}

2004年 4 月から 2017 年 3 月までの13年間に NHS 要再検で当センターに紹介され, 精密聴力検査を受 けた220名と同期間にNHS パス例であったが，難 聴が疑われ, 当センターに紹介となり難聴が判明し た45名を対象とした。この 265 名に対し，聴力の程 度と補装具の使用状況, 耳鼻咽喉科初診年齢と当セ ンター初診年齢, 難聴の原因因子と聴力が正常だ が，NHS 要再検になった原因に関して調査を行っ た。

聴力評価は, 初診時, 聴性行動反応聴力検查 (behavioral observation audiometry, BOA), 条件詮 索反応聴力検查 (conditioned orientation response 
audiometry, COR), 遊戯聴力検査, 標準純音聴力 検查を年齢, 発達に応じて行った。当日または後日 に聴性脳幹反応検査（ABR）の閾値と聴性定常反応 （ASSR）を用いた。聴力が安定し，遊戯聴力検査や 標準純音聴力検査が安定して行える症例は，2017年 3 月時点での最新の平均聴力とした。BOAまたは COR で, 検査結果が安定しない症例については, 最終の ABR の閾値と ASSR の推定聴力を比較し, 信頼度の高い值を平均聴力とした。難聴の程度は, 4 分法による平均聴力をもとに, $25 \mathrm{~dB}$ HL 以上 40 $\mathrm{dB}$ HL 未満を軽度難聴, $40 \mathrm{~dB}$ HL 以上 $70 \mathrm{~dB}$ HL未 満を中等度難聴, $70 \mathrm{~dB}$ HL 以上 $90 \mathrm{~dB}$ HL未満を高 度難聴，90dB HL 以上を重度難聴に分類した。し かし, BOA や COR で, 対象児の集中力の問題から, 検査の閾值が上昇する場合があったため, ASSR上 も軽度難聴が疑われる場合は, $25 \mathrm{~dB} \mathrm{HL}$ でなく, 30 $\mathrm{dB}$ HL 以上を軽度難聴と判断した。また, 聴力の 左右差がある場合は，良聴耳の結果で分類した。

$\mathrm{BOA}, \mathrm{COR}$, 遊戯聴力検査, 標準純音聴力検査 はリオン株式会社製 $\mathrm{AA}-\mathrm{H} 1$ を使用。ABR はリオン 株式会社製 Auderaを使用し，音刺激はクリック音 を用いてヘッドホンで行い, 加算回数は1000回, V 波闇值で 40dBnHL 以上を難聴ありの基準とした。 ASSR もリオン株式会社製 Auderaを使用し， 250 $8000 \mathrm{~Hz}$ の周波数変調音を用い, 250，500，1000, 2000， $4000 \mathrm{~Hz}$ の気導間值を測定した。

調査にあたっては, (1)NHS 両側要再検後, 両側 難聴診断症例(2)NHS 両側要再検後, 一側難聴診断 症例(3)NHS 一側要再検後, 両側難聴診断症例(4) NHS 一側要再検後, 一側難聴診断症例(5)NHS 要再 検後, 難聴なし診断症例(6)NHS パス後, 両側難聴 診断症例(7)NHS パス後, 一側難聴診断症例に対象 を分類し，調査した。

難聴の原因検索については, NHS 要再検後, 当 初難聴が認められ, 加療により, 最終的に滲出性中
耳炎が改善し，難聴なしになった症例は，滲出性中 耳炎を NHS が referであった原因因子とした。他 に, CT, MRI の画像検査を施行し, 奇形の有無を 確認した。さらに，他院で明らかな遺伝学的診断が ついていない場合，また明らかな原因因子が確定し ていない時点で，保護者の同意が得られれば，遺伝 学的検査が可能な他院を紹介し, 次世代シークエン ス法, インベーダー法での遺伝学的検查を施行し, 遺伝学的検索を施行した。サイトメガロウイルス感 染症 (CMV) については, 難聴の診断がつき, 精 査を希望される場合, 臍帯での検査を行った。

\section{結果}

\section{1. 精密聴力検査結果}

当センターにNHS で難聴が疑われ，紹介された 両側要再検児は122名, 一側要再検児は98名であっ た。精密聴力検查結果を表 1 に示す。両側要再検 後, 両側難聴と診断された症例は107名 $(87.7 \%)$, 一側要再検後, 一側難聴と診断された症例は53名 （54.1\%）であった。一側要再検で両側難聴と診断 された症例は 25 名 $(25.5 \%)$ であった。

NHS がパスであったが，難聴を疑われ当セン夕 一紹介となり難聴の診断となった症例が 45 名であ り, 両側難聴が32名 $(71.1 \%)$, 一側難聴が13名 (28.9\%) であった。

2. 聴力の程度と補装具の使用状況

両側難聴における聴力の程度を表 2 , 一側難聴に おける聴力の程度を表 3 , 補装具の使用状況を表 4 に示す。両側要再検で両側難聴と診断された症例で は, 中等度難聴が最も多く, 54 名 $(50.5 \%)$, 次が 39名（36.4\%）の重度難聴であった。補装具は両側 要再検後, 両側難聴の全員が装用していた。

一側要再検で両側難聴と診断された症例は，中等 度難聴が最も多く，14名（56\%）で，次が 9 名 $36 \%$ の軽度難聴であった。一側要再検後，両側難聴児 25

表 1 精密聴力検査結果

\begin{tabular}{|c|c|c|c|}
\hline & 両側難聴 & 一側難聴 & 難聴なし \\
\hline 襾側要再検 122 名 & 107名 $(87.7 \%)$ & 3名 $(2.5 \%)$ & 12 名 $(9.8 \%)$ \\
\hline 一側要再検 98名 & 25名 $(25.5 \%)$ & 53名 $(54.1 \%)$ & 20 名 $(20.4 \%)$ \\
\hline NHS パス後, 難聴 45名 & 32名 $(71.1 \%)$ & 13 名 $(28.9 \%)$ & \\
\hline
\end{tabular}


名全員が補装具を装用していた。

NHS パス例における 32 名の両側難聴児では, 中 等度難聴が10名（31.3\%）で最も多かった。次が軽 度難聴と重度難聴の 8 名（25\%）であった。補装具 を装用できなかったのは 3 名 $(9.4 \%)$ だった。 1 名は重度の知的障害があり, 補聴器への拒否反応が 強く, 補聴器の使用には至らなかった。他の 1 名は 家族が補聴器の装用を希望せず，もう 1 名は 2000 $\mathrm{Hz}$ と $4000 \mathrm{~Hz}$ が軽度の難聴であり, 補聴器を試聴 したものの装用を希望しなかったため定期的に聴力 の管理を行いながら経過観察となった。
一側要再検で一側難聴と診断された症例の聴力の 程度は高度難聴が一番多く, 22 名 (41.5\%) で, 補 聴器を14名（26.4\%）が装用していた。補聴器を装 用している難聴の程度は，中等度難聴が最も多く, 13名中 6 名であった。

NHS パス例における一側難聴児の聴力の程度 は，中等度難聴が最も多く，6名 $(46.2 \%)$ だっ た。 5 名 $(38.5 \%)$ が補聴器を装用し, その中で, 3 名が中等度難聴であった。

3. 平均耳鼻咽喉科初診年齢と平均当科初診年齢 平均初診年齢を表 5 に示す。NHS 両側または一

表 2 両側難聴における聴力の程度

\begin{tabular}{|l|c|c|c|c|}
\hline & \multicolumn{1}{|c|}{ 軽度難聴 } & 中等度難聴 & 高度難聴 & 重度難聴 \\
\hline 両側要再検後両側難聴 : 107名 & 3名 $(2.8 \%)$ & 54 名 $(50.5 \%)$ & 11 名 $(10.3 \%)$ & 39 名 $(36.4 \%)$ \\
\hline 一側要再検後両側難聴 : 25名 & 9名 $(36 \%)$ & 14名 $(56 \%)$ & 0 名 & 2名 $(8.0 \%)$ \\
\hline NHS パス後両側難聴 : 32名 & 8名 $(25 \%)$ & 10名 $(31.3 \%)$ & 6 名 $(18.7 \%)$ & 8名 $(25 \%)$ \\
\hline
\end{tabular}

表 3 一側難聴における聴力の程度

\begin{tabular}{|l|c|c|c|c|}
\hline & 軽度難聴 & 中等度難聴 & 高度難聴 & 重度難聴 \\
\hline 両側要再検後一側難聴：3名 & 0名 & 0名 & 0名 & 3名 $(100.0 \%)$ \\
\hline 一側要再検後一側難聴：53名 & 5名 $(9.4 \%)$ & 13名 $(24.5 \%)$ & 22名 $(41.5 \%)$ & 13名 $(24.5 \%)$ \\
\hline NHS パス後一側難聴 : 13名 & 2名 (15.4\%) & 6名 (46.2\%) & 1名 $(3.1 \%)$ & 4名 $(12.5 \%)$ \\
\hline
\end{tabular}

表 4 補装具の使用状況

\begin{tabular}{|c|c|c|c|}
\hline & 補聴器 & 人工内耳 & 補装具なし \\
\hline 両側要再検後両側難聴：107名 & 79名（73.8\%） & 28名（26.2\%） & 0名 \\
\hline 一側要再検後両側難聴：25名 & 24 名（96.0\%） & 1名 $(4.0 \%)$ & 0名 \\
\hline NHS パス後両側難聴：32名 & 21名 (65.6\%) & 8名 $(25.0 \%)$ & 3名 $(9.4 \%)$ \\
\hline 両側要再検後一側難聴：3名 & 1名（33.3\%） & 0名 & 2名 $(66.7 \%)$ \\
\hline 一側要再検後一側難聴：53名 & 14名 (26.4\%) & 0名 & 39名 $(73.6 \%)$ \\
\hline NHS パス後一側難聴：13名 & 5名（38.5\%） & 0名 & 8名 $(61.5 \%)$ \\
\hline
\end{tabular}

表 5 平均初診年齢

\begin{tabular}{|l|c|c|}
\hline & 平均耳鼻咽喉科初診年齢 & 平均当センター初診年齢 \\
\hline 両側要再検後両側難聴 : 107名 & 2.9 カ月 & 10.4 カ月 \\
\hline 一側要再検後両側難聴 : 25名 & 2.2 カ & 8.1 月 \\
\hline NHS パス後両側難聴 : 32名 & 43.3 月 & 46.9 月 \\
\hline 両側要再検後一側難聴 : 3名 & 0.7 月 & 4.3 月 \\
\hline 一側要再検後一側難聴 : 53名 & 1.8 月 & 11.7 月 \\
\hline NHS パス後一側難聴 : 13名 & 44.1 月 & 46.7 月 \\
\hline
\end{tabular}


側要再検後の症例では平均 2 か月で耳鼻咽喉科を初 診して抢り, 当センターの初診年齢の平均は生後 4 カ月から11カ月であった。NHSパス後について は，両側また一側難聴とも40力月台（3歳台）に耳 鼻咽喉科及び当センターを初診していた。

4. 原因因子

両側難聴の原因因子を図 1 に示す。両側要再検 後, 両側難聴診断症例では遺伝的素因を原因とする 難聴が48名（44\%）を占め, 中でも非症候群性が24 名 (22\%) と最も多かった。遺伝的素因以外で多か ったのが, $\mathrm{CMV}$ の 7 名（7\%）であった。一側要 再検後, 両側難聴診断症例では， 6 名（24\%）に遺
伝的素因を認めその中でも染色体異常が 4 名 （16\%）と最も多かった。NHSパス後，両側難聴診 断症例では，遺伝的素因が 9 名（28\%）で非症候群 性難聴が最も多く 7 名 $(22 \%)$, 内耳奇形 3 名 (9\%), CMVが3名（9\%）であった。NHSパス 後, 两側難聴診断症例の遺伝的素因の中で, Auditory neuropathy spectrum disorder (ANSD) の症例 が 2 名認められた。

一側難聴の原因因子を図 2 に示す。一側要再検後 一側難聴診断症例では, 外耳道閉鎖（狭窄）症が10 名（19\%）と最も多かった。NHS パス後一側難聴 診断症例においても外耳道狭窄症が最も多く， 3 名

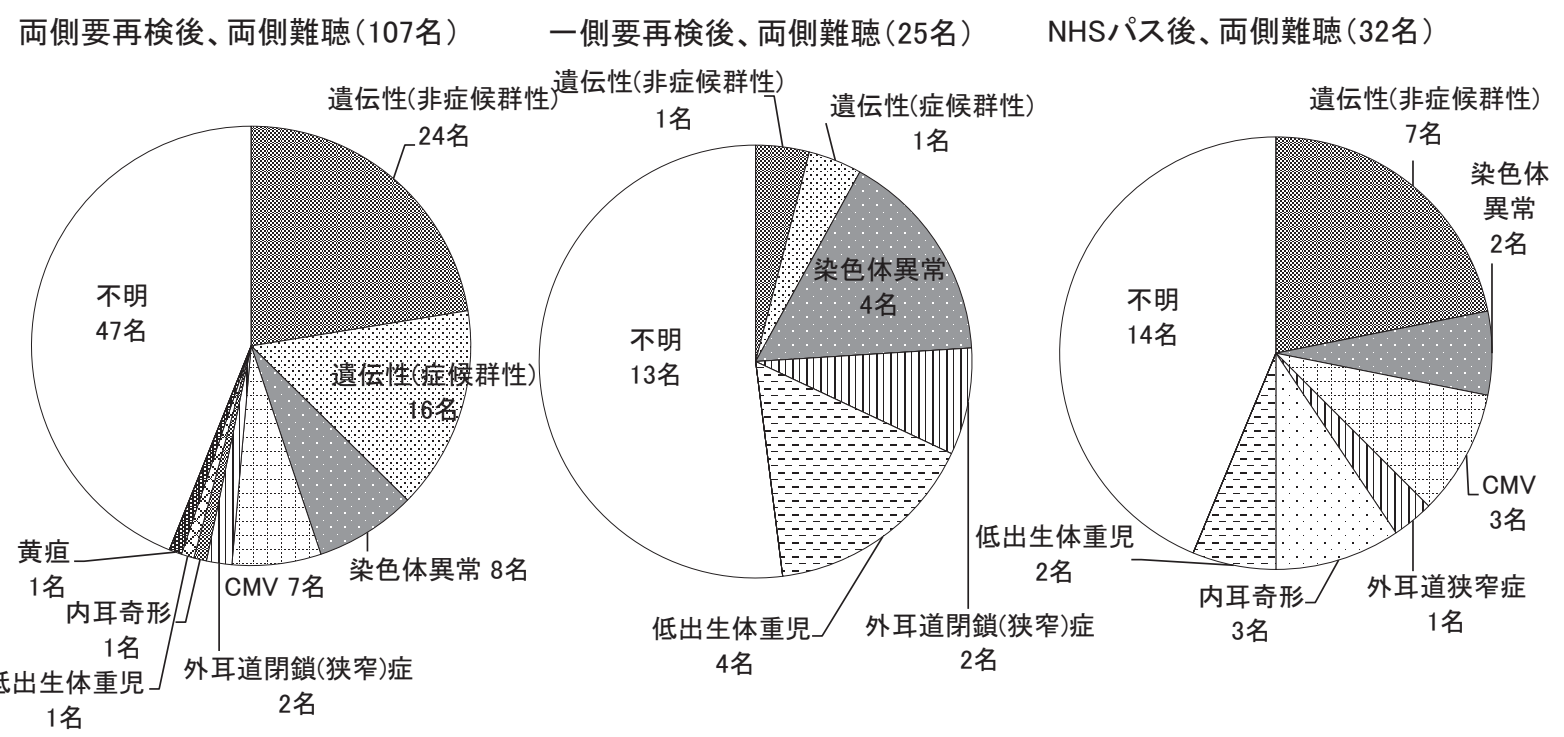

図 1 两側難聴診断症例の原因因子

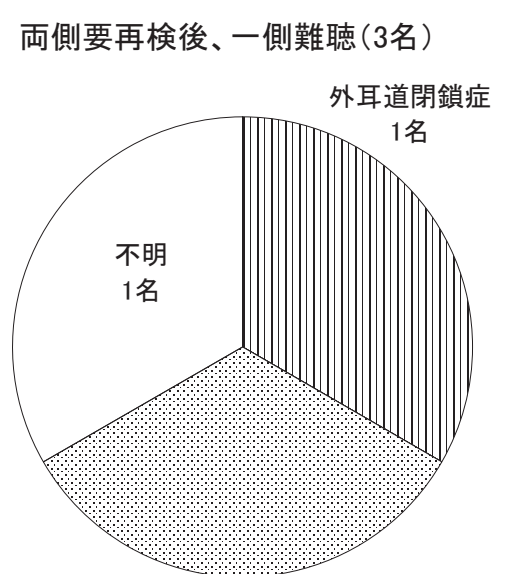

重症新生児仮死 1名 33\%

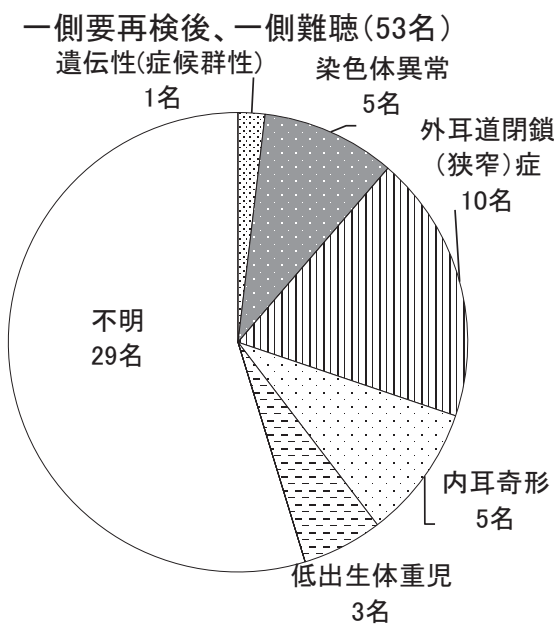

図2一側難聴診断症例の原因因子

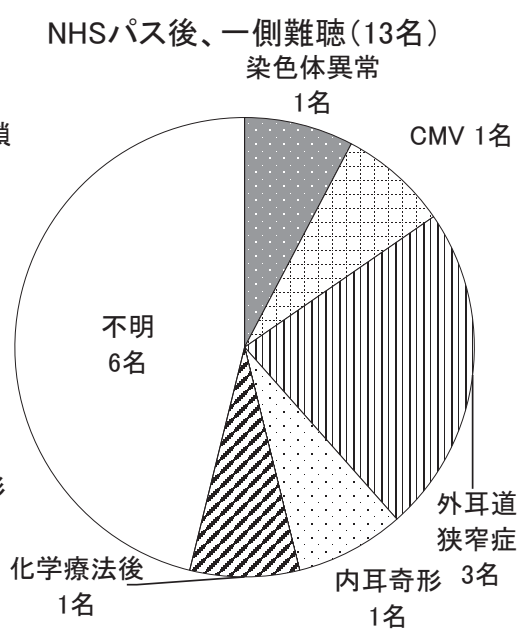

1名 

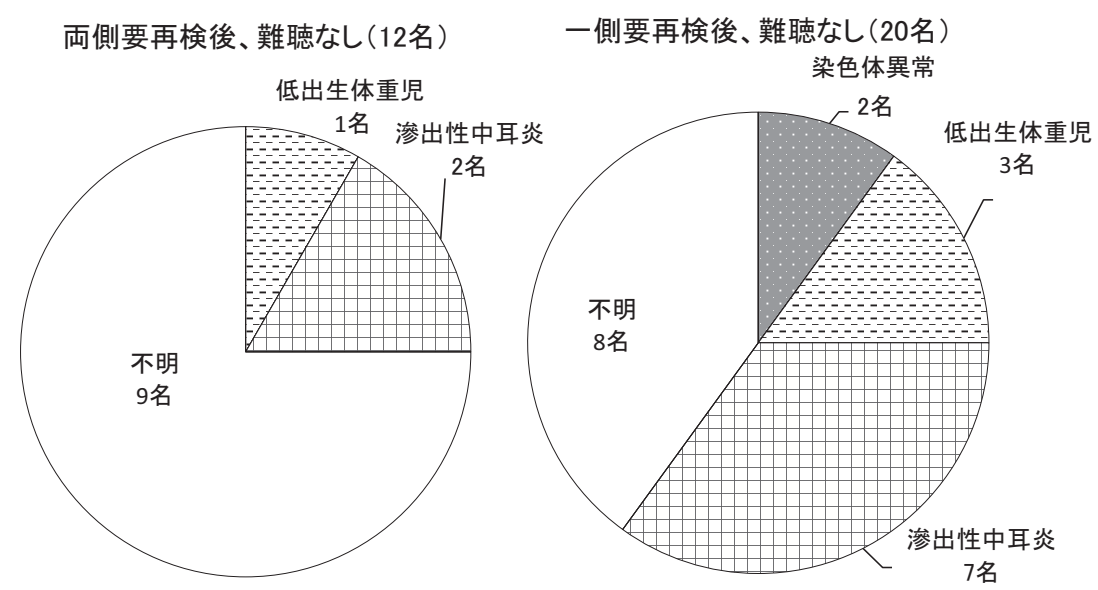

図３NHS 要再検後, 難聴なし診断症例の原因

（23\%）に認められた。

NHS 要再検後，難聴なし診断症例の原因を図 3 に示す。最も多かったのは滲出性中耳炎で, 一側要 再検で 7 名 $(35 \%)$, 両側要再検で 2 名 $(17 \%)$ で あった。その次は, 低出生体重児で一側要再検にお いて 3 名 $(15 \%)$, 両側要再検において 1 名 (8\%) であった。一側要再検では, 染色体異常が 2 例 （10\%）認められた。

\section{考察}

当センターの NHS 後の陽性的中率は, 両側要再 検後両側難聴の $87.7 \%$, 一側要再検後一側難聴の $54.1 \%$, 一側要再検後両側難聴の $25 \%$ であり, 日本 耳鼻咽喉科学会の全国調查の報告 ${ }^{1)}$ の両側要再検後 両側 難聴の $22.6 \%$, 一側要再検後一側難聴の $19.7 \%$, 一側要再検後両側難聴の $4.4 \%$ と比較する とかなり高い值となった。この原因については, 福 島県における自動 ABR の保有率は $97.3 \%$ で, 厚生 労働省の平成 26 年度の調查結果の検查実施状況の自 動 ABR 使用率 $79.7 \%$ と比較すると高い。NHS 機器 として OAE はNHS として $5 \%$ 程度の偽陽性率が あるとの報告 ${ }^{2}$ もあり，福島県では，自動 $\mathrm{ABR} の$ 保有率が高いことから, 精度が高くなった原因の一 つと考えられた。また, 福島県の NHS が要精查に なった症例は, 直接療育施設である当センターに紹 介されず，二次精查機関に紹介される症例も多く， そこで ABRが施行され, 難聴が強く疑われた症例 のみ当センターに紹介される。そのため, 二次精査 機関で NHS 偽陽性症例は難聴が否定され, 当セン
ターにまで紹介されることはない。これも陽性的中 率が高くなった原因の一つと考えられた。

一側要再検で両側難聴と NHS パス例における両 側難聴の症例では, 軽度難聴と中等度難聴が多く, 後発性あるいは進行性の難聴であった可能性と偽陰 性の結果がでた可能性が示唆された。そのため, 一 側要再検であっても, 両側難聴の可能性があり,

NHS パス側の聴力が悪化する可能性や軽度または 中等度難聴で偽陰性になった可能性を念頭において 経過を追っていく必要があると考えられた。

一側難聴診断症例の補装具の使用状況は, 中等度 難聴では約半数が補聴器の装用をしていたが, 軽度 難聴では補聴器を装用している症例はいなかった。 軽度難聴児は難聴の自覚も少なく, 装用効果を自覚 できなかったためと考えられた。当センターでは, 一側難聴症例に対し, 難聴の診断が確定した時点 で, 聴力から予想されうる補聴器の装用効果や幼少 時の装用の難しさについて説明を行っている。一側 重度難聴児でも補聴器を装用している症例もいた が，登下校時等の危険回避目的に補聴器を装用する も, 補聴器の使用を中止していた症例も多かった。 当センターでは, 補聴器装用を中止した症例にも, 将来, クロス補聴器の使用を紹介する予定である。 また, 聴力や聞き取りの問題等がないか, 定期的に 経過観察を行っている。

NHS 要再検後, 両側難聴症例の平均耳鼻咽喉科 初診年齢は2.9力月にも関わらず，平均当センター 初診年齢は 10.4 力だった。 6 力月から補装具を使 った療育訓練開始を目標にするため 3 カ月以内での 
受診が望ましいが，福島県は地域が広く，精密医療 機関が 4 施設しかないため, 初診が遅れる原因にも なっている。NHS 再検後, 精密医療機関が遠いた め, 近くの別の医療機関を受診される症例も多く, $\mathrm{ABR}$ 検査を $2 \sim 3$ 回行って, 経過を 7 力月まで追 ってから，当センターを紹介される症例も多い。 $\mathrm{ABR}$ 検査の 1 回目で, 難聴が疑われれば, すぐに 当センターを紹介されるシステム作りが必要と考え られた。当センターに扔いて療育中の難聴児の 19. 3\%が NHS パス症例であり, NHS パス後, 両側 難聴症例の平均初診年齢は, 3 歳台とかなり遅く, 療育機関の介入がかなり遅れることがわかった。こ の結果から, NHS がパスして, 音への反応があっ たとしても，言葉の遅れがある場合は，精密医療機 関へ紹介するよう保健師に啓蒙していく必要がある と考えられた。

原因因子については, 両側要再検後両側難聴の $44 \%$, 一側要再検後両側難聴の $24 \%$, NHS パス後 両側難聴の $28 \%$ が遺伝的素因であり, Morton ${ }^{22} ら の$ 小児期発症の両側難聴の 60 ～70\%は遺伝子の関与に よるものであったとの報告と比較するとかなり低い 值となった。当センターでは, 全症例に遺伝子検査 を施行していないため, 低い值となったと考えられ た。

NHS パス後, 一側難聴で, 外耳道狭窄症が一番 多かった原因は, 高音域の聴力が正常範囲であった ためと考えられた。NHSパス後, 両側難聴の診断 された Auditory neuropathy の症例は, NHS 機器が OAE だったため，NHSがパスしたと考えられた。 CMV が NHS 要再検後の難聴診断症例の原因とし ても多くみられたが, NHS パス後, 難聴診断症例 にもみられており, 小川芀が指摘しているように, 出生時に他症状の一部が発症している場合や，まっ たく無症状でのちに聴覚障害や神経学的後遺症を発 症する場合があるため, 他症状があるが先天性難聴 を認めていない症例であっても, 注意して経過観察 していく必要があると考えられた。

NHS 要再検後, 難聴なし診断症例の原因で一番 多かった滲出性中耳炎については，滲出性中耳炎の 改善とともに，聴力が正常化したと考えられた。泰 地 ${ }^{4)}$ が報告しているように, NHS は耳垢栓塞や外 耳道狭窄，中耳炎があると検出できない点で注意が
必要であり，今回の結果からも滲出性中耳炎による 偽陽性に注意して精査を進めていく必要があること がわかった。NHS 要再検後, 難聴なし診断症例の 原因として，他に低出生体重児や染色体異常がみら れた。水野ら ${ }^{5)}$ のNHS 後の調查においても, 聴覚 闇值が改善した症例には，合併奇形や発達障害のハ イリスク児が多く渗出性中耳炎も散見されたと報告 している。

泰地 ${ }^{6}$ は, 中枢系の未成熟のために NHS 要再検 になる可能性と ABRの閾值上昇・波形分離不良が 起こることを報告している。さらに，そのほとんど がNICU 児またはダウン症などの発達障害を伴う 例であり，MRIにて脳幹の髄鞘化不全が認められ ることがあり, NICU 児やダウン症児では ABRの 結果は将来改善してくる場合があり, 聴力が正常化 する可能性もあることを踏まえて，対応すべきとも 報告している。NICUに入院するような低出生体重 児や染色体異常児では聴力の確定診断が 1 歳台であ り，1歳時までは，ハイリスク児は聴力の変動の可 能性があり, この可能性を念頭に置いて，慎重に経 過を追ってみていく必要がある。そのため, 当科で は, ハイリスク児に対し, 就学前まで年 $2 \sim 3$ 回程 度の聴力管理, $\mathrm{ABR}$ の閾值上昇・波形分離不良が ある場合は, 就学後も年 $1 \sim 2$ 回程度の聴力管理を 行っている。

今回の調査から, 両側難聴症例では, 補聴器, 人 工内耳の装用指導ができていた。しかし, 当センタ 一に紹介される時期が遅く, 聴覚補償が遅れている 実態がわかった。このため, 市町村の保健師や産婦 人科医だけでなく，二次的な医療機関に対して も，1-3-6ルールの徹底を行い，早急に療育機関 に紹介されるようなフローチャートの作成やシステ 厶を作る必要があると考えられた。また，原因因子 によっては, 聴力の変動があり, 経過を追っていく 必要があることがわかった。

\section{まと め}

福島県における NHS 業が開始された2004年から 2017年まで当センターにおける精密聴力検査の結果 について報告した。さらに同時期における NHS パ ス児で精密聴力検查を施行された症例に関しても報 告した。両側難聴が明らかとなった症例では聴覚補 
償がなされていた。しかし，NHS 要再検後，二次 的な医療機関で，長く経過観察され，療育が遅れた 症例もいた。この問題点への対応が今後の課題であ ることがわかった。原因因子によっては, 聴力の変 動があり, 聴力の変動に注意して, 経過を追ってい く必要があることがわかった。

\section{倫理的配慮}

本調查は福島県総合療育センター倫理委員会に承 認（承認番号：30-11）された。

本報告の要旨は, 第62回日本聴覚医学会（2016年 福岡県福岡市), 第63回日本聴覚医学会 (2017年兵 庫県神戸市）で口演した。

利益相反に該当する事項はない。

\section{Survey of Deaf Children Examined at our Center over the 13-year Period since the Commencement of Newborn Hearing Screenings}

Yukie Suzuki ${ }^{1)}$, Mitsuyoshi Imaizumi ${ }^{2)}$, Yoko Baba $^{3)}$, Teruhisa Suzuki ${ }^{4)}$, Naoko Yamada ${ }^{1)}$, Aya Harata $^{1)}$, Reiko Kuroda ${ }^{2)}$, Koushi Ootsuki ${ }^{2)}$, Daisuke Kikuchi' ${ }^{2}$, Hiroshi Ogawa ${ }^{5}$

${ }^{1)}$ Fukushima Rehabilitation Center for Children

${ }^{2)}$ Fukushima Medical University Department of Otolaryngology

${ }^{3)}$ Baba clinic

${ }^{4)}$ Ear, Nose and Throat Suzuki Clinic

${ }^{5)}$ Aizu Medical Center

Thirteen years after the start of newborn hearing screenings (hereinafter, "NHS") at the Fukushima General Rehabilitation Center starting in April 2004, we conducted a survey of 220 patients who had undergone the precision hearing testing and 45 patients who were deemed to have passed the NHS but went on to become deaf, and collected data on the subjects' hearing test results, their use of supportive devices, and the causative factors for deafness. Among the 233 deaf children receiving rehabilitation at this center, $45(19.3 \%)$ had passed the NHS, indicating that early detection of progressive/late-onset deafness in children is also vital. Most of the children who were deaf in both ears after receiving the recommendation of one side needing closer examination and passing the NHS had mild/moderate deafness in both ears. The most common causative factors were hereditary factors in the cases of deafness in both ears, and meatal stenosis in the cases of deafness in one ear.

\section{参考文献}

1）日本耳鼻咽喉科学会 福祉医療・乳幼児委員 会: 平成 25 年度「新生児聴覚スクリーニング後 の精密聴力検査機関の実態調査」に関する報告.

日耳鼻 $117: 746-748,2014$

2 ) Morton CC, Nance: Newborn hearing screening: a silent Revolution. N Engl J Med 354 : 2151-2164, 2006

3 ）小川 洋：ウイルスと小児難聴.耳喉頭頸 86 : 133-139, 2014

4 ) 泰地秀信, 守本倫子, 川城信子: 新生児 - 乳 幼児における ABR と DPOAEの比較検討. Audiology Japan 48 : 121-127, 2005

$5 ）$ 水野知美, 佐藤輝幸, 高橋 辰：当科におけ る新生览聴覚スクリーニング13年間の検討.

Audiology Japan 58 : 638-647, 2015

6 ）泰地秀信：乳幼児難聴の聴覚医学的問題「聴 覚検查に打ける問題点」. Audiology Japan 54: 185-196, 2011

(2019年3月4日受稿 2019年12月9日受理)

別冊請求先 : $\bar{\top} 963-8041$

福島県郡山市富田町字上ノ台 4-1

福島県総合療育センター

鈴木雪恵

Yukie Suzuki

Fukushima Rehabilitation Center for Children

4-1, Uenodai, Tomita-machi, Koriyama, Fukushima, 963-8041, Japan 